\title{
KEPEMIMPINAN PENDIDIKAN ISLAM (Analisis Makna Kata "Khalifah" dalam Al Qur'an)
}

\author{
Oleh: \\ M. Yusuf Agung Subekti \& Mochamad Nurcholiq \\ Dosen Pada STAI Ma'had Al Al Hikam Malang - Indonesia \\ Email: yusembon@gmail.com \\ Email: choliq7791@gmail.com
}

\begin{abstract}
To interpret thematically is to determine the topic. The topic of this discussion is the meaning of "caliph" and its relationship to the theme of educational leadership. The word caliph in the singular is repeated only 2 times, the jamaic

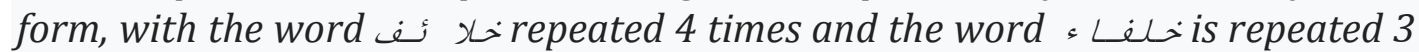
times. The meaning of the khalifah contained in the Qur'an is a description of the role and function of leadership. The description of "khalifah" in accordance with the concept that is synchronized with Zikr-Pikr and Mikr, which in the meaning of the word Zikr is remember or conscious, with zikr in every activity will always be aware and able to control themselves, its means using the mind to always make new innovations and always be creative, and then Pikr is the tought of Mikr in the form of ideas or innovations and creations in the form of programs and their implementation.
\end{abstract}

\begin{abstract}
Abstrak
Untuk melakukan penafsiran secara tematik adalah menentukan topik. Topik pada pembahasan ini adalah makna "khalifah" dan hubungannya dengan tema kepemimpinan pendidikan. Kata khalifah dalam bentuk tunggal diulang hanya 2 kali, bentuk jama', dengan kata خلاء خلف terulang sebanyak 4 kali dan kata خلف terulang sebanyak 3 kali. Makna khalifah yang termaktub dalam Al Qur'an merupakan gambaran dari peran dan fungsi kepemimpinan. Gambaran "khalifah" sesuai dengan konsep yang diakronimkan dengan Zikr-Pikr dan $M i k r$, yang dalam arti katanya Zikr adalah ingat atau sadar, dengan zikr dalam setiap aktivitas akan selalu sadar dan dapat mengontrol diri, Mikr berarti menggunakan akal pikiran untuk selalu membuat inovasi baru dan selalu berkreasi, dan berikutnya Pikr merupakan buah dari Mikr yaitu berupa hasil pemikiran atau inovasi dan kreasi yang berupa program-progam dan pelaksanaannya.
\end{abstract}

Key Word: Kepemimpinan Pendidikan, Makna Khalifah Al Qur'an 


\section{A. Pendaluluan}

Kehadiran Al Qur'an yang dipandang sebagai hudan (petunjuk) ${ }^{1}$ di tengah umat Islam bagaikan representasi dari kehadiran Tuhan dan RasulNya untuk selalu meyertai dan selalu berdialog dengan mereka, sehingga ia dapat memecahkan persoalan hidup yang dihadapi umat manusia. Pergumulan yang sangat intens antara Al Qur'an dengan dinamika sosial sangat mencolok pada masa Rasulullah. Ayat-ayat Al Qur'an yang diturunkan secara bertahap membuatnya mampu berdialog dengan realitas sosial kala itu, akibatnya Al Qur'an tidak sekedar dinikmati keindahan gramatika dan bahasanya saja melainkan dapat membangkitkan kesadaran dalam diri pendengar dan pembacanya untuk bergerak dan berbuat sesuai arahan-arahan yang diberikannya. Bahkan, dikatakan bahwa kajian tafsir Al Qur'an lebih dahulu daripada metodologinya. ${ }^{2}$

Pada masa Rasulullah ayat-ayat Al Qur'an yang diwahyukan selalu menimbulkan dinamika wacana dalam masyarakat. Ayat-ayatnya selalu terlibat dalam sebuah dialog kehidupan secara dinamis dan terbuka. Ayatayat Al Qur'an yang secara intens berdialog dengan bangsa Arab kala itu dengan mudahnya merasuk dalam kesadaran mereka, karenanya Al Qur'an kala itu tidak tertulis dalam sebuah mushhaf melainkan tertulis dalam lubuk hati setiap orang yang beriman. ${ }^{3}$ Dan Redaksi ayat-ayat Al Qur'an, tidak semua dapat dijangkau maksudnya secara pasti, kecuali oleh pemilik redaksi tesebut. Hal inilah yang kemudian menimbulkan keanekaragaman penafsiran. ${ }^{4}$

Perbedaan penafsiran terhadap teks suci Al Qur'an semakin memperluas horizon pemahaman umat Islam tentang kandungan pesanpesan Tuhan di satu sisi. Namun di sisi lain, semakin banyaknya penafsiran

\footnotetext{
${ }^{1}$ Hasan Hanafi, Al-Yamin wa Al Yasar Fi Al-Fikr Al-Diniy, (Mesir: Madbuliy, 1989). Hal. 77. Pemahanan umat terhadap Al-Qur'an itulah yang bisa menjadi menjadi penerang bagi majunya umat. Pemahaman disini mencakup penafsiran terhadap Al-Qur'an. Penafsiran pada masa Rasul bersumber dari rasul sendiri melalui al wahyu al-ilahiyi atau melalui para sahabat yang berkompeten pada penafsiran (ijtihad al-sohabi). Para sahabat ini mempunyai keutaman-keutamaan dalam menjelaskan nash-nash. Lihat dalam Abdul Wahab Khallaf, Sejarah Hukum Islam: Ihtisar dan Dokumentasinya, (Bandung: Mardja, 2005), Hlm. 13

2 Ali Hasan Al-Aridl, Sejarah dan Metodologi tafsir, tarj. Ahmad Akrom (Jakarta: Rajawali Press, 1992), Hlm. v

${ }^{3}$ Komaruddin Hidayat, Memahami bahasa Agama, ( Jakarta: Paramadina, 1996), hlm. 170-171

4 M. Quraish Shihab, Membumikan Al Qur'an: Fungsi dan Peran Wahyu dalam Kehidupan Masyarakat, (Bandung, MIzan: 1999). Cet. XX. HIm. 75
} 
tersebut apabila tidak dibarengi dengan sikap keterbukaan akan menimbulkan idiologisasi terhadap pemahaman-pemahaman tertentu yang muncul akibat penafsiran itu.

Islam mengenal dua orientasi metode dalam pemahaman teks suci Al Qur'an, ${ }^{5}$ kelompok skripturalis dan kelompok substantif. Kelompok skripturalis memahami bahwa penafsiran dan pemahaman Al Qur'an bersifat absolut. Absolutisasi pemahaman tersebut terjadi karena asumsi bahwa Al Qur'an sebagai kalam Allah telah final penafsirannya oleh Rasul. Sedangkan kelompok subtantif berasumsi bahwa penafsiran dan pemahaman Al Qur'an bersifat relatif. Relatifitas penafsiran tersebut didasari oleh preposisi bahwa Al Qur'an adalah pesan-pesan Tuhan yang diturunkan dalam bahasa Arab secara bertahap agar sejalan dengan dinamika zaman.

Al-Qur'an sebagai the way of life tidaklah cukup dipahami hanya dengan penguasaan bahasa Arab dan mengetahui terjemahannya. Untuk memperoleh penafsiran yang tepat dan meraih ruh dari maksud Al-Qur'an memerlukan rambu-rambu dalam bingkai ilmu tafsir. ${ }^{6}$ Mayoritas ulama membagi tafsir menjadi 4 bagian, yaitu: tafsir tahlili, ${ }^{7}$ tafsir ijmali, 8 tafsir muqarin ${ }^{9}$ serta tafsir maudhu'i. ${ }^{10}$

5 Metode dalam bahasa Arab biasanya disebut dengan "al-manhaj" atau "al-thariqat, altanawih." Menurut Dr. Ibrahim Syarif definisi metode adalah suatu cara atau alat untuk menganalisasikan tujuan aliran-aliran tafsir. Lihat dalam Ridlwan Nasir, Memahami Al-Qur'an, (Surabaya: Indra Media, 2003), Hlm 14

و علم يبحث عن مراد الله تعالى بقدر الطاقة البثرية, فهو شـامل لكل مـايتوقف عليه فهم المعنى وبيـان المراد. membahas maksud Allah ta'ala sesuai dengan kadar kemampuan manusiawi yang mencakup segala sesuatu yang berkaitan dengan pemahaman dan penjelasan makna. Lihat dalam Muhammad Husain Adz-Dzahabi.'Ilmu At-Tafsir. (Kairo: Dar Al-Ma'arif, t.th). hal. 6

7 Para ulama membagi wujud tafsir Al-Qur'an dengan metode tahlili kepada tujuh macam, yaitu: tafsri bi-al ma'tsur, tafsri bi al-ra'yi, tafsri shufi,tafsir falasafi, tafsir fiqhi, tafsri ilmi dan tafsir adabi. Lihat dalam Al- Sa'id Aqil Husain Al Munawar. Al-qur'an Membangun Tradisi Kesalehan Hakiki.( Jakarta: Ciputat Pres, 2002). Hlm. 69-73. Al-Tafsir al-Tahlily adalah suatu metode tafsir yang bermaksud menjelaskan kandungan ayat-ayat al-Qur'an dari seluruh aspeknya. Di dalam tafsirnya, penafsir mengikuti urutan ayat-ayat sebagai mana yang telah tersusun dalam mushaf. Lihat dalam M. M Al-A'Zami, Sejarah Texs Al-Qur'an dari wahyu sampai Kompilasi. Judul Asli: The History of The Qur,anic Text: From Revelation to Compilation A comparative Study with the old and New Testaments. Terj: Sohirin Solihin dkk. Cet. 1-(Jakarta: GEma Insani Press, 2005). Hlm.

${ }^{8}$ Al-Tafsir al-Ijmaly adalah suatu metode tafsir yang menafsirkan ayat-ayat al-Qur'an dengan cara mengemukakan makna global. Nasruddin Baidan mengatakan, Metode ijmaliy adalah menjelaskan ayat-ayat al-Qur'an secara ringkas tapi mencakup, dengan bahasa yang populer, mudah dimengerti, dan enak dibaca. Lihat dalamNasruddin Baidan, Metode Penafsiran Al- 
Tulisan ini berupaya mengungkap dan memaparkan makna kata "khalifah" dalam Al-Qur'an dengan menggunakan metode maudhu'i yang secara berurutan akan dibahas bagaimana kata "khalifah" dimaknai dari aspek kebahasaannya, penafsiran ayatnya, serta kaitannya dengan manajemen pendidikan pada saat ini terutama tentang bagaimana sosok seorang pemimpin yang seharusnya.

\section{B. Pembahasan}

\section{Kerangka Penafsiran dengan Metode Maudhu'i}

Apa yang dinamakan dengan tafsir tahlili adalah bagaikan hidangan prasmanan, sedangkan menyodorkan kepada para tamu sebuah kotak makanan adalah ilustrasi dari tafsir maudhu'i. Tafsir maudhu'i mempunyai dua macam bentuk kajian, yaitu: 1). Pembahasan mengenai satu surat secara menyeluruh dan utuh dengan menjelaskan maksudnya yang bersifat umum dan khusus, menjelaskan korelasi antara berbagai masalah yang dikandungnya, sehingga surat itu tampak dalam bentuknya yang betul-betul utuh dan cermat.; 2). menghimpun sejumlah ayat dari berbagai surat yang sama-sama membicarakan satu masalah tertentu; ayat-ayat tersebut disusun sedemikian rupa dan diletakkan pada satu tema bahasan, dan selanjutnya ditafsirkan secara maudhu'i.11

Abdul Hay Al-Farmawiy, Pada tahun 1977 mengemukakan secara terinci langkah-langkah yang hendaknya ditempuh untuk menerapkan metode maudhu'i, yaitu: ${ }^{12} 1$ ). Menetapkan masalah yang akan dibahas (topik); 2). Menghimpun ayat-ayat yang berkaitan dengan masalah tersebut; 3). Menyusun runtutan ayat sesuai dengan masa turunnya,

Qur'an. Kajian Terhadap Ayat-Ayat Yang Beredaksi Mirip. Cet- I (Jakarta: pustaka pelajar, 2002). Hlm. 31

9 Menurut Nasruddin Baidan, yang dimaksud dengan metode komperatif adalah: a) membandingkan teks (nash) ayat-ayat al-Qur'an yang memiliki persamaan atau kemiripan redaksi dalam dua kasus atau lebih, dan atau memiliki redaksi yang berbeda bagi satu kasus yang sama. b) membandingkan ayat Al-Qur'an dengan hadis yang pada lahirnya tampak bertentangan, c) membandingkan berbagai pendapat ulama tafsir dengan menafsirkan alQur'an. Ibid, HIm. 34

${ }^{10}$ Secara istilah tafsir Maudhu'iy adalah mengumpulkan ayat-ayat al-Qur'an yang mempunyai tujuan yang satu, bersama-sama membahas topik/judul sektor tertentu dan menertibkannya sedapat mungkin sesuai dengan masa turunnya selaras dengan sebab-sebab turunnya, kemudian memperhatikan ayat-ayat tersebut dengan penjelasan-penjelasan, keteranganketerangan dan hubungan-hubungannya dengan ayat-ayat lain, kemudian mengistinbatkan hukum-hukum.

11 M. Quraish Shihab, Wawasan Al Qur'an: Tafsir Maudhu'I atas Pelbagai Persoalan Umat, (Jakarta: Mizan, 2001), Cetakan XII. Hlm. Xii-xiii

12 'Abdul Hay Al-Farmawiy, Al-Bidayah fi Tafsir Al-Mawdhu'iy, (Kairo, Al-Hadharah Al'Arabiyah: 1977), cetakan II. Hlm. 62. 
disertai pengetahuan tentang asbab al-nuzul-nya; 4). Memahami korelasi ayat-ayat tersebut dalam suratnya masing-masing; 5). Menyusun pembahasan dalam kerangka yang sempurna (outline); 6). Melengkapi pembahasan dengan hadis-hadis yang relevan dengan pokok bahasan; 7). Mempelajari ayat-ayat tersebut secara keseluruhan dengan jalan menghimpun ayat-ayatnya yang mempunyai pengertian yang sama, atau mengkompromikan antara yang 'am (umum) dan yang khash (khusus), mutlak dan muqayyad (terikat), atau yang pada lahirnya bertentangan, sehingga kesemuanya bertemu dalam satu muara, tanpa perbedaan atau pemaksaan.

Diantara kelebihan dari metode ini adalah bahwa ia dapat Menjawab tantangan zaman, Praktis dan sistematis, Dinamis, serta dapat membuat pemahaman menjadi utuh. Sedangkan sisi negative dari ini adalah adanya peemenggalan ayat al-Qur'an serta membatasi pemahaman ayat Karena sifatnya berbenuk tematik tersebut.

Dengan demikian, Tafsir dengan metode Maudhu'i lebih dapat diandalkan untuk menjawab permasalahan. Kedudukan metode ini menjadi semakin kuat dalam khazanah intelektual Islam. Terjadinya pemahaman yang parsial dalam memahami ayat-ayat al-Qur'an, adalah sebagai akibat tidak dikajinya ayat-ayat tersebut secara menyeluruh. Hal ini sangat berbahaya karena dapat menimbulkan kontradiktif atau penyimpangan yang jauh dalam memahami ayat-ayat al-Qur'an. Dalam metode tematik hal itu tidak akan terjadi.

M. Quraish Shihab mengungkapkan prasyarat utama dalam menerapkan metode maudhu'I adalah diperlukannya keahlian akademis, karena itu kehati-hatian dan ketekunan sangat diperlukan. ${ }^{13}$ Di samping itu, juga diperlukan sikap "rendah hati" dalam menafsirkan Al Qur'an, apalagi dengan metode ini.

\section{Khalifah; Tinjauan Kebahasaan}

Sebagai telah disinggung sebelumnya, bahwa langkah awal untuk melakukan penafsiran secara maudhu'i adalah menentukan dulu topik atau masalah yang akan dijawab oleh Al-Qur'an. Di sini, topik atau masalahnya sudah ada, yaitu, apakah yang dimaksud khalifah menurut AlQur'an? Lalu setelah itu kita harus menginventarisasi ayat-ayat yang berbicara tentang khalifah. Kata khalifah dalam bentuk tunggal diulang hanya dua kali, yaitu dalam surah Al-Baqarah 30,14 dan dalam surah Shad ayat 26.15

13 M. Quraish Shihab, Wawasan Al Qur'an... Hlm. xiv

${ }^{14}$ Surat AL Baqarah ayat 30 
Secara gramatikal, Khilafah menurut makna bahasa merupakan mashdar dari fi'il madhi - خلف,- berarti: menggantikan atau menempati tempatnya. ${ }^{16}$ Makna khilafah menurut Ibrahim Anis bermakna من بعده فسمعناه adalah "orang yang datang setelah orang lain lalu menggantikan tempatnya. ${ }^{17}$ Hal ini dikatakan bahwa khilafah dikaitkan dengan penggantian karena orang yang kedua datang setelah orang yang pertama dan menggantikan kedudukannya. Menurut Imam ath-Thabari, makna bahasa inilah yang menjadi alasan mengapa as-sulthan al-a'zham (penguasa besar umat Islam) disebut sebagai khalifah, karena dia menggantikan penguasa sebelumnya, lalu menggantikan posisinya. ${ }^{18}$

Dalam Mu'jam Tafsir ${ }^{19}$ disebutkan bahwa khilafah merupakan bentuk masdar dari khalafa yang mempunyai makna الامة الباقية بعد الامة السابقة (umat yang berikut setelah umat yang dahulu). Sedangkan dalam Al Mawrid kata Khalifah dimaknai dengan من يخلف غيره yang diartikan dengan "successor" atau "caliph".20

Louis Ma'luf Al Yasu'i dan Bernard Tottel Al Yasu'i dalam Al Munjid 21 juga memberikan definisi "khalifah" dengan عمد من اعدة البيت في Ah مؤخره. Sedangkan menurut Quraish Shihab, asal kata khalifah adalah "dibelakang" dan kareana arti ini, maka khalifah sering diartikan sebagai pengganti (karena yang menggantikan selalu dibelakang, atau datang sesudah yang digantikan. ${ }^{22}$

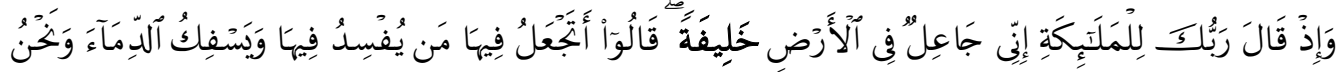

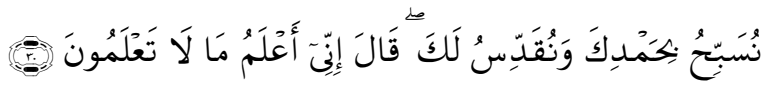

${ }^{15}$ Surat Shaad Ayat 26

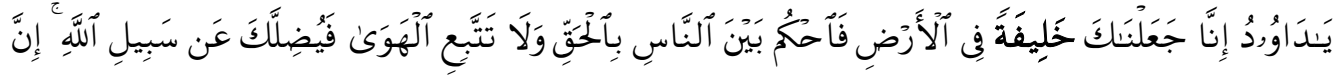

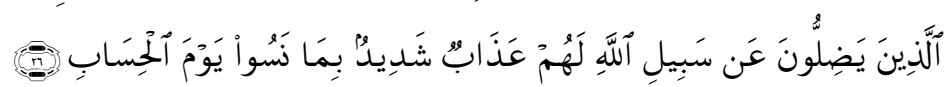

${ }^{16}$ Ahmad Warson Munawwir, Kamus Al-Munawwir. (Yogyakarta : PP. Al-Munawwir Krapyak, 1999). Hlm.390

${ }^{17}$ Ibrahim Anis, et.al. Al-Mu'jam Al-Wasith. (Kair : Darul Ma'arif,1972). Jilid I, Hlm. 251

${ }^{18}$ Ibnu Jarir Al Thabari, Tafsir Al THabari, (Beirut: Dar al Fikr, t.th) Juz II. Hlm. 199

${ }^{19}$ Samikh 'Atif Al Zain, Mu'jam Tafsiir Muftadaat Alfadz al Qur'an Al Karim, Fefeteenth Edition. (Beirut: Dar All Kitab Al Lubnaniy, 2001) Hlm. 288-289

${ }^{20}$ Rokhi Al Ba'labaki, Al Mawrid: A Modern Arabic-English Dictionary, (Beirut: Dar Al 'Ilmi Al Malayin, 2001), Hlm. 523

${ }^{21}$ Louis Ma'luf Al Yasu'i dan Bernard Tottel Al Yasu'i, Al Munjid fi Al Lughah wa al A'lam (Beirut: Dar Al Masyriq, 2000). Cet. Ke-38. Hlm 193

${ }^{22}$ M. Quraish Shihab, Membumikan Al Qur'an, (Bandung: Mizan, 1977) Hlm. 157 
Beberapa pengertian lughawi di atas kiranya dijadikan salah satu dasar dalam mengartikan makna "klalifah" dalam Kamus Besar Bahasa Indonesia, yaitu: 1). wakil (pengganti) Nabi Muhammad setelah Nabi wafat (dalam urusan negara dan agama) yang melaksanakan syari'at Islam; 2). Gelar kepala negara dalam negara Islam, 3). Penguasa, pengelola. ${ }^{23}$

Sedangkan dalam bentuk jama', Nanang Ghozali mengemukkan bahwa kata khalifah ${ }^{24}$ dengan kata خلا ئف terulang sebanyak 4 kali, yakni pada surat Al An'am: 165, ${ }^{25}$ Surat Yunus: 14 dan 73, ${ }^{26}$ serta surat al Fatir: 39. ${ }^{27}$ sedangkan bentuk jama' dengan menggunakan kata خلفاء terulang sebanyak 3 kali, yaitu pada surat Al a'raf: 69 dan $74^{28}$ serta surat an Naml: 62.29

23 Tim Penyusun Kamus Pusat Bahasa, Kamus Besar Bahasa Indonesia, Edisi Tiga, (Jakarta: Balai Pustaka, 2002) Hlm. 563.

24 Nanang Ghozali, Nanang Gozali, Manusia, Pendidikan dan Sains dalam Pandangan Tafsir Hermenutik. (Jakarta: Rineka Cipta, 2004). Hlm. 81

25 Surat Al An'am ayat 165:

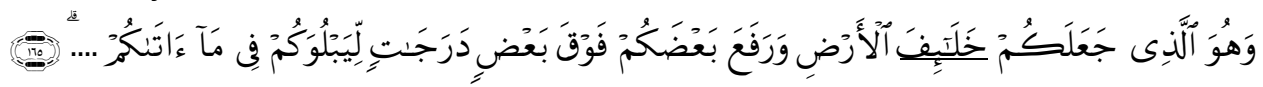
${ }^{26}$ Surat Yunus ayat 14 dan 73

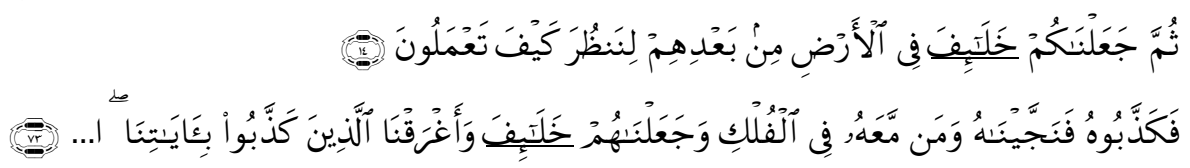

27 Surat Al Fatir: 39

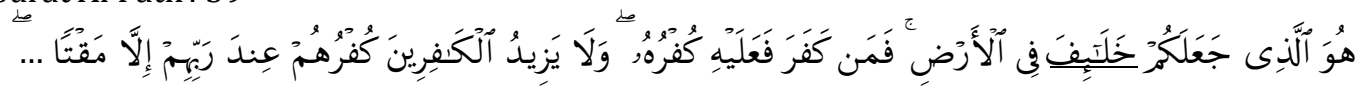

28 Surat Al-'Araf 69 dan 74.

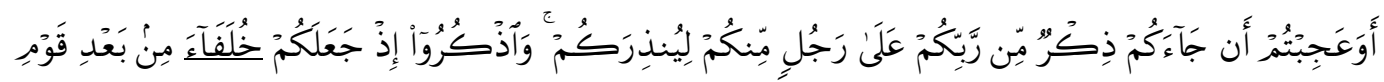

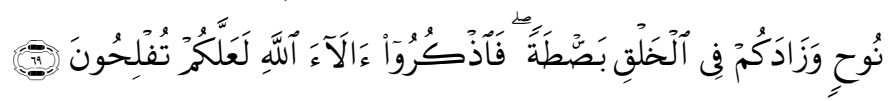

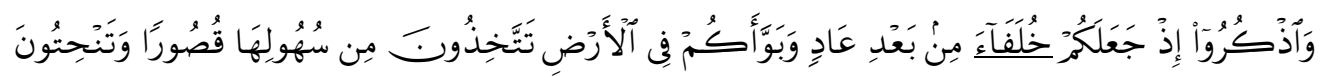

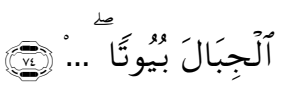

${ }^{29}$ Surat An Naml ayat 62

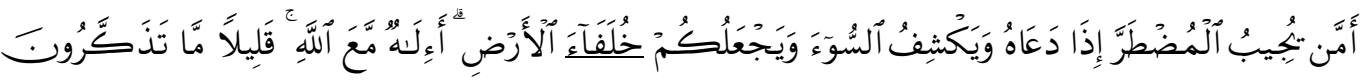


Dalam pengertian syariah, Khilafah digunakan untuk menyebut orang yang menggantikan Nabi Saw dalam kepemimpinan Negara Islam (ad-dawlah al-Islamiyah). Inilah pengertiannya pada masa awal Islam. Kemudian, dalam perkembangan selanjutnya, istilah Khilafah digunakan untuk menyebut Negara Islam itu sendiri.

Hanya saja, para ulama mempunyai sudut pandang yang berbedabeda ketika memandang kedudukan Khilafah. Sebagian ulama memandang Khilafah sebagai penampakan politik (al-mazh-har as-siyasi), yakni sebagai institusi yang menjalankan urusan politik atau yang berkaitan dengan kekuasaan (as-sulthan) dan sistem pemerintahan (nizham al-hukm). Sementara sebagian lainnya memandang Khilafah sebagai penampakan agama (al-mazh-har ad-dini), yakni institusi yang menjalankan urusan agama. Maksudnya, menjalankan urusan di luar bidang kekuasaan atau sistem pemerintahan, misalnya pelaksanaan mu'amalah (seperti perdagangan), al-ahwal asy-syakhshiyyah (hukum keluarga, seperti nikah), dan ibadah-ibadah mahdhah. Ada pula yang berusaha menghimpun dua penampakan ini. Adanya perbedaan sudut pandang inilah yang menyebabkan mengapa para ulama tidak menyepakati satu definisi untuk Khilafah. ${ }^{30}$

Berdasarkan pengertian di atas, maka makna khalifah disini mempunyai 2 makna:

1. Kelompok Pertama, menerangkan hakikat Khilafah sebagai sebuah kepemimpinan umum bagi seluruh kaum muslimin di dunia.

2. Kelompok Kedua, menjelaskan tugas-tugas khalifah, yaitu: (1) tugas menerapkan seluruh hukum-hukum syariah Islam, (2) tugas mengemban dakwah Islam di luar tapal batas negara ke seluruh bangsa dan umat dengan jalan jihad fi sabilillah.

Maknanya berkisar pada kata kerja "menggantikan", "meninggalkan", atau kata benda "pengganti", atau pewaris. Secara terminologis, kata ini mengandung setidaknya dua makna ganda. Di satu pihak, khalifah diartikan sebagai kepala negara dalam pemerintah dan kerajaan Islam masa lalu, yang dalam kontek kerajaan pengertiannya sama dengan sultan. Di lain pihak, khalifah juga berarti dua macam. Pertama, diwujudkan dalam jabatan sultan atau kepala negara. Kedua, fungsi manusia itu sendiri di muka bumi sebagai ciptaan Allah SWT yang

30 Mahmud Abdul Majid Al-Khalidi, Qawaid Nizham Al-Hukm fi Al-Islam. (Kuwait: Darul Buhuts Al-'Ilmiyah, 1980 ). Hlm. 227 
JURNAL PIWULANG, Vol. 2 No. 1 September 2019, 64-82

sempurna.

\section{Khalifah Sebagai Konsep Dasar Kepemimpinan}

Pada dasarnya Al qur’an tidak pernah menyebutkan kata kepemimpinan secara tersirat, karena kata kepemimpinan merupakan istilah dalam manejemen dalam organisasi. Dalam manejemen, kepemimpinan merupakan suatu faktor yang mempengaruhi berhasil atau tidaknya suatu organisasi. Memang benar organisasi akan berhasil manakala sistem pemodalan (in put) berjalan lancar, struktur organisasinya rapi dan berjalan, dan tenaga terampilnya tersedia, tetapi kepemimpinan memegang peranan penting dalam suatu kepemimpinan, ${ }^{31}$ suatu organisasi akan berhasil apabila kepemimpinan dipegang oleh orang yang baik dan jujur. Sebaliknya apabila dipegang oleh orang yang dhalim dan berjiwa penghianat, maka kehancuran yang layak ditunggunya. Dengan kata lain kepemimpinan merupakan faktor yang menjadi penentu pada efektivitas dan efisiensi kegiatan organisasi.

Sebutan kepemimpinan muncul ketika seorang memiliki kemampuan dan mengarahkan perilaku orang lain, kepribadian khas, memiliki kecakapan dan sifat-sifat yang khusus yang tidak dimiliki oleh orang lain. Apabila ciri-ciri tersebut dikaitkan pada mobilisasi massa, maka lahirlah istilah pemimpin massa. Jika dikaitkan dengan organisasi kedinasan pemerintah maka dinamakan jabatanan pimpinan. Jika dikaitkan dengan dengan administrasi maka dinamakan administrator.

Meskipun demikian, bukan berarti Al qur`an tidak membicarakan sama sekali masalah kepemimpinan, bahkan Al qur’an banyak menyebutkan masalah kepemimpinan seperti dalan surat Al Baqarah ayat 30:

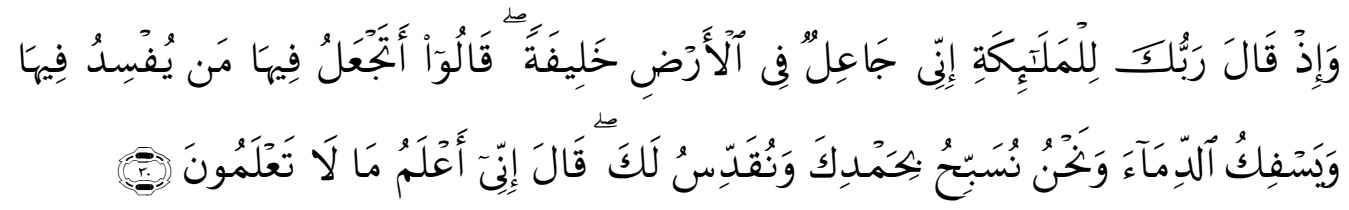

"Dan ingatlah ketika Tuhanmu berfirman kepada Para Malaikat:

"Sesungguhnya aku hendak menjadikan seorang khalifah di muka

31 Kepemimpinan adalah usaha yang dilakukan oleh seseorang dengan segenap kemampuan yang dimilikinya untuk mempengaruhi, mendorong, mengarahkan dan menggerakkan individu-individu supaya mereka mau bekerja dengan penuh semangat dan kepercayaan dalam mencapai tujuan-tujuan organisasi. LIhat dalam Burhanuddin, Analisis Administrasi Manajemen dan Kepemimpinan Pendidikan , (Jakarta,: Bumi Aksara, 1994) , Hlm. 63 
bumi." mereka berkata: "Mengapa Engkau hendak menjadikan (khalifah) di bumi itu orang yang akan membuat kerusakan padanya dan menumpahkan darah, Padahal Kami Senantiasa bertasbih dengan memuji Engkau dan mensucikan Engkau?" Tuhan berfirman: "Sesungguhnya aku mengetahui apa yang tidak kamu ketahui." (Q.S.

\section{Al Baqarah: 30)}

Dalam surat Shaad ayat 26 tentang "khalifah" yang diberikan kepada Nabi Daud a.s sebagai berikut:

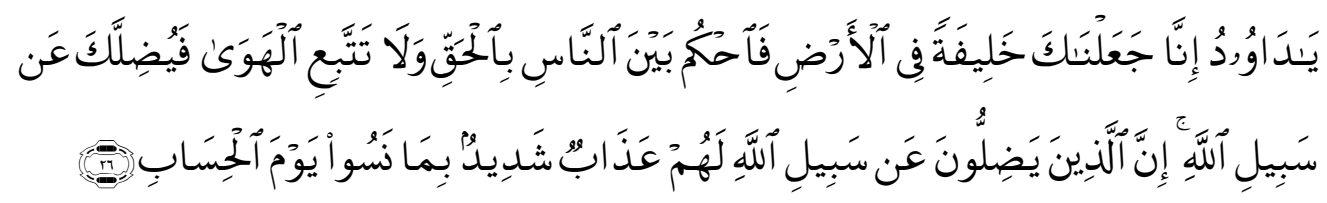

"Hai Daud, Sesungguhnya Kami menjadikan kamu khalifah (penguasa) di muka bumi, Maka berilah keputusan (perkara) di antara manusia dengan adil dan janganlah kamu mengikuti hawa nafsu, karena ia akan menyesatkan kamu dari jalan Allah. Sesungguhnya orang-orang yang sesat darin jalan Allah akan mendapat azab yang berat, karena mereka melupakan hari perhitungan. (Q.S. Shaad: 26)

Pada Surat Al Baqarah: 30, sebagian ulama memandang ayat ini bagian dari ayat mutasyabihat, karena dalam ayat ini diilustrasikan ada dialog terbuka antara Allah Swt dengan para malaikat ketika Allah berencana akan menjadikan makhluk manusia sebagai khalifah di bumi. Jika dialog itu betul-betul terjadi maka pertanyaan-pertanyaan yang akan muncul dan tidak terhindarkan adalah 1) bagaimana dialog itu berlangsung, 2) di mana dan kapan terjadinya? Pertanyaan-pertanyaan tersebut tentu tidak relevan untuk dijawab apabila dikaitkan dengan Allah Swt. sebagai Dzat Yang Mulia dan Maha Suci dari ketergantungan terhadap makhluk-Nya. Kecuali itu, penolakan para malaikat yang digambarkan dalam ayat ini, juga bertentangan dengan sifat dasar mereka yang selalu setia melaksanakan perintah Allah Swt.

Apabila kedua ayat tentang pengangkatan Daud a.s. (surat Shaad: 26) dan Adam a.s. (surat Al-Baqarah: 30) diperbandingkan dari segi susunan redaksinya, maka terlihat bahwa sekurang-kurangnya terdapat dua hal yang membedakannya. Pertama, pengangkatan Adam sebagai khalifah oleh Allah dijelaskan dalam bentuk tunggal " إنّي " (sesungguh- 
nya Aku), sedangkan pengangkatan Daud dijelaskan dalam bentuk plural "إنَ" (sesungghnya Kami). Kedua, kalimat predikat yang digunakan dalam pengangkatan Adam ialah جاعل (akan menjadikan/mengangkat), sedangkan dalam pengangkatan Daud digunakan kata kerja جاعلناك (Kami telah menjadikan/mengangkat).

Apabila kita menerima kaidah yang menyatakan bahwa penggunaan bentuk plural untuk menunjuk kepada Allah mengandung makna keterlibatan pihak lain bersama Allah dalam pekerjaan yang ditunjuknya, maka berarti bahwa dalam pengangkatan Daud sebagai khalifah terdapat keterlibatan pihak lain selain Allah, yakni masyarakat (pengikut-pengikutnya). Adapun Adam, maka di sini wajar apabila pengangkatannya digambarkan dalam bentuk tunggal, bukan saja disebabkan karena ketika itu ke-khalifah-an yang dimaksud baru berupa rencana (Aku akan mengangkat...), tetapi juga karena saat peristiwa ini terjadi tidak ada pihak lain bersama Allah yang terlibat dalam pengangkatan tersebut. Ini berarti bahwa Daud -dan semua khalifah- yang terlibat dengan masyarakat dalam pengangkatannya, dituntut untuk memperhatikan kehendak masyarakat tersebut/ karena mereka ketika itu termasuk pula sebagai mustakhlif. ${ }^{32}$

Dalam menyikapi ayat-ayat seperti ini, di kalangan ulama tafsir terdapat dua kelompok pandangan, yaitu: ${ }^{33}$

1. Ulama tafsir dari generasi salaf (sahabat dan tabi'in) memandang dialog yang digambarkan dalam ayat tersebut di atas sebagai suatu fakta Qur'ani yang tanpa reserve wajib diimani apa adanya. Hanya saja persoalan bagaimana dialog itu berlangsung dan kapan serta di mana terjadinya, tidak patut dipertanyakan, apalagi dijawab.

2. Ulama tafsir dari generasi khalaf (pasca tabi'in) khususnya kaum mu'tazilah, berpandangan bahwa dialog yang digambarkan dalam ayat tersebut sebagai ungkapan simbolik yang bertujuan untuk lebih memudahkan pemahaman tentang proses sejarah kehidupan manusia di muka bumi, Artinya, bukan proses berlangsungnya dialog yang harus menjadi perhatian kita, melainkan pesan substantif dari simbolisasi dialog tersebut yang harus Rita tangkap maknanya. Dengan demikian maka ulama dalam kelompok ini lebih

\footnotetext{
32 Nanang Ghozali, Manusia, Pendidikan dan Sains dalam Pandangan Tafsir Hermenutik.... Hlm. 84

${ }^{33}$ Nanang Gozali, Manusia, Pendidikan dan Sains dalam Pandangan Tafsir Hermenutik. (Jakarta: Rineka Cipta, 2004). HIm. 71
} 
mengedepankan penggunaan takwil ${ }^{34}$ ketimbang tafsir. ${ }^{35}$ Menurut mereka, apabila terjadi kontradiksi antara ayat dengan penalaran, maka ayat tersebut dapat ditakwilkan kepada makna bathinnya sehingga ada persesuaian antara keduanya.

Mengikuti perbedaan sikap dan pandangan ulama salaf dan khaaf tersebut, kita yang hidup jauh dari pasca "khalaf" sendiri merasa beruntung tidak mesti bersusah payah menentukan sikap dan pandangan sendiri mengenai ayat-ayat mutasyabih ini. Jika tidak menggabungkan kedua pandangan tersebut, maka sekurang-kurangnya mengikuti atau memperkuat salah satunya.

Ayat ini bersama-sama ayat penciptaan Adam yang lain, menjelaskan bahwa sebelum Adam telah ada beberapa jenis makhluk selain manusia. Di antaranya adalah malaikat yang tidak dapat kita ketahui sosoknya dan tidak dapat diteliti dengan ilmu pengetahuan. Dia termasuk masalah metafisika yang berada di luar jangkauan ilmu pengetahuan. ${ }^{36}$ Pengetahuan kita tentang malaikat tidak lebih dan tidak kurang dari apa yang dijelaskan dalam Al-Qur'an, yaitu makhluk statis yang tidak punya pilihan kecuali tunduk dan patuh serta tidak pemah membangkang kepada perintah Allah. ${ }^{37}$

Dalam ayat ini pula disebutkan masalah kepemimpinan manusia pertama yakni Nabi Adam AS, bahkan sebelum beliau diciptakan oleh Allah SWT, dan surat Yunus ayat 14 disebutkan:

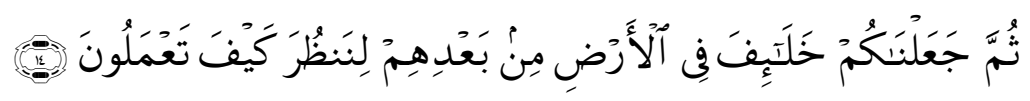

Kemudian Kami jadikan kamu pengganti-pengganti (mereka) di muka bumi sesudah mereka, supaya Kami memperhatikan bagaimana kamu berbuat. (Q.S. Yunus: 14)

Dan lebih tegas lagi disebutkan dalam surat Al An`am ayat 165.

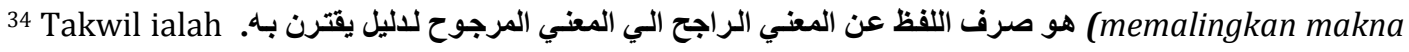
suatu lafadz dari makna yang seharusnya kepada makna yang tidak seharusnya karena ada qarinah yang memalingkannya. Lihat, Al Dazhabi Muhammad Husain. Al Tafsir wa Al Mufassiruun Juz I. (Mesir: Maktabah Wahbah, 2000).Cet. Ke-7. HIm. 18

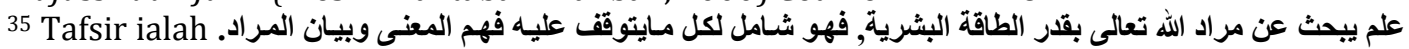
(Ilmu yang membahas maksud Allah ta'ala sesuai dengan kadar kemampuan manusiawi yang mencakup segala sesuatu yang berkaitan dengan pemahaman dan penjelasan makna.. .Lihat dalam Muhammad Husain Adz-Dzahabi.'Ilmu At-Tafsir. (Kairo: Dar Al-Ma'arif, t.th). hal. 6 36 Aisyah Binti al Syathi', Manusia Sensivitas Hermeneutika Al Qur'an, (Yogyakarta: LKPSM, 1997), HIm. 30

37 Lihat Surat Al Tahrim ayat 6
}

- M. Yusuf Agung Subekti \& Mochamad Nurcoliq - 75 


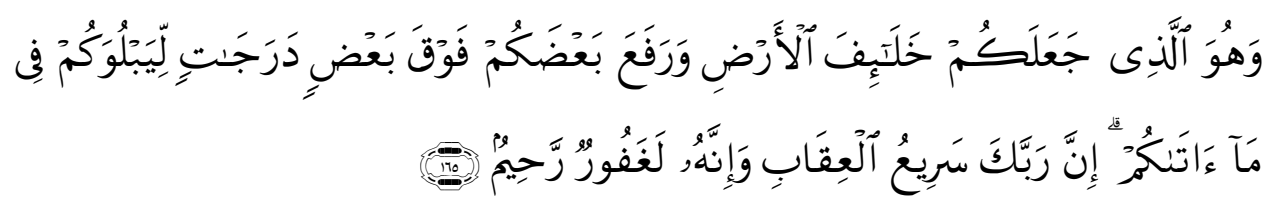

"dan Dia lah yang menjadikan kamu penguasa-penguasa di bumi dan

Dia meninggikan sebahagian kamu atas sebahagian (yang lain) beberapa derajat, untuk mengujimu tentang apa yang diberikan-Nya kepadamu. Sesungguhnya Tuhanmu Amat cepat siksaan-Nya dan Sesungguhnya Dia Maha Pengampun lagi Maha Penyayang. (Al An'am: 165)

Tidak dikuatirkan adanya perlakuan sewenang-wenang dari khalifah yang diangkat Tuhan itu selama ini benar-benar menyadari arti kekhalifahannya. Karena, Tuhan sendiri memerintahkan kepada para khalifahnya untuk selalu bermusyawarah dan berlaku adil. Tidak dapat dipungkiri, bahwa dalam sejarah, terdapat khalifah-khalifah yang berlaku sewenang-wenang dengan alasan bahwa mereka adalah wakil Tuhan di bumi. Namun, di sini mereka sangat keliru dalam memahami dan mempraktekkan kekhalifahan itu.

Dengan demikian, makna khalifah dalam Al Qur'an mempunyai beberapa implikasi yaitu adanya hubungan antara manusia dengan alam atau hubungan manusia dengan sesamanya, bukan merupakan hubungan antara penakluk dan yang ditaklukkan, atau antara tuan dengan hambanya, tetapi hubungan kebersamaan dalam ketundukan kepada Allah Swt. Karena, walaupun manusia mampu mengelola (menguasai), mempmpin, namun hal tersebut bukan akibat kekuatan yang dimilikinya, tetapi akibat Tuhan menundukkannya untuk manusia. Ini tergambar antara lain dalam firman-Nya, pada n Al-Zukhruf ayat 13.

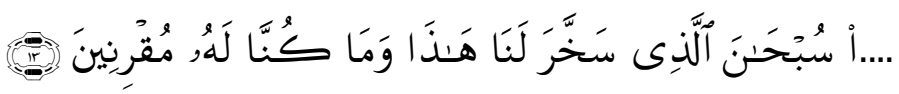

"Maha suci Tuhan yang telah menundukkan semua ini bagi Kami Padahal Kami sebelumnya tidak mampu menguasainya. (Q.S. Az Zuhruuf: 13)

Demikian itu, sehingga ke-khalifah-an menuntut adanya interaksi antara manusia dengan sesamanya dan manusia dengan alam sesuai dengan petunjuk-petunjuk ilahi yang tertera dalam wahyu-wahyu-Nya. 
Semua itu harus ditemukan kandungannya oleh manusia sambil memperhatikan perkembangan situasi lingkungannya.

Kata sakhara yang dimaknai "menundukkan" kiranya kurang tepat digunakan, tetapi, hubungan satu sama lain adalah hubungan al-taskhir, dalam arti semua dalam kedudukan yang sama dan yang membedakan mereka hanyalah partisipasi dan kemampuan masing-masing. Adalah logis apabila yang "kuat" lebih mampu untuk memperoleh bagian yang melebihi perolehan yang "lemah".

Ayat di atas mengisyaratkan bahwa keitimewan tidak dimonopoli oleh suatu lapisan atau bahwa ada lapisan masyarakat yang ditundukkan oleh lapisan yang lain. Karena, jika demikian maknanya, maka ayat tersebut tidak akan menyatakan agar mereka dapat saling mempergunakan.

Inilah prinsip pokok yang merupakan landasan interaksi antara sesama manusia dan keharmonisan hubungan itu pulalah yang menjadi tujuan dari segala etika agama. Keharmonisan hubungan inilah ying menghasilkan etika itsar, sehingga etika agama tidak mengenal prinsip "Anda boleh melakukan apa saja selama tidak melanggar hak orang lain," tetapi memperkenalkan "Mereka mendahulukan pihak lain atas diri mereka meskipun mereka sendiri dalam kebutuhan."38

\section{Konsep Kepemimpinan dalam Pendidikan Islam}

Dalam Islam istilah kepemimpinan dikenal dengan kata Imamah, sedangkan kata yang terkait dengan kepemimpinan dan berkonotasi pemimpin dalam Islam ada tujuh macam, yaitu Khalifah, Malik, Wali, 'Amir dan Ra'in, Sultan, Rais, dan Ulil 'amri. ${ }^{39}$ Kata khalifah sebagai focus penulisan ini berakar dari kata khalafa yang pada mulanya berarti "di belakang". Al-Qur'an menggunakan kedua istilah ini untuk menggambarkan ciri seorang pemimpin, ketika di depan menjadi panutan, dan ketika di belakang mendorong, sekaligus mengikuti kehendak dan arah yang dituju oleh yang dipimpinnya. Hal ini sesuai dalam istilah jawa yang dipopulerkan oleh Ki Hadjar Dewantara "ing ngarso sung tulodo, ing madya mbangun karsa, tut wuri handayani".

\footnotetext{
${ }^{38}$ Nanang Ghozali, Manusia, Pendidikan dan Sains... Op. Cit. Hlm. 86-87

39 Abdurrahman, M. Dinamika Masyarakat Islam dalam Wawasan Fikih, (Bandung: Remaja Rosdakarya, 2002) Hlm.
} 
Menurut kodrat serta irodatnya bahwa manusia dilahirkan untuk menjadi pemimpin. Sejak Adam diciptakan sebagai manusia pertama dan diturunkan ke Bumi, Ia ditugasi sebagai Khalifah fil ardhi. Sebagaimana termaktub dalam Al Quran Surat Al Baqarah ayat 30. Menurut Bachtiar Surin yang dikutip oleh Maman Ukas bahwa "Perkataan Khalifah berarti penghubung atau pemimpin yang diserahi untuk menyampaikan atau memimpin sesuatu". ${ }^{40}$ Di sini, Pemimpin pada hakikatnya adalah seorang yang mempunyai kemampuan untuk memepengaruhi perilaku orang lain di dalam kerjanya dengan menggunakan kekuasaan. ${ }^{41}$

Dalam kegiatannya bahwa pemimpin memiliki kekuasaan untuk mengerahkan dan mempengaruhi bawahannya sehubungan dengan tugas-tugas yang harus dilaksanakan. Pada tahap pemberian tugas pemimpin harus memberikan suara arahan dan bimbingan yang jelas, agar bawahan dalam melaksanakan tugasnya dapat dengan mudah dan hasil yang dicapai sesuai dengan tujuan yang telah ditetapkan. Oleh sebab itu bahwa pemimpin diharapakan memiliki kemampuan dalam menjalankan kepemimpinannya, kareana apabila tidak memiliki kemampuan untuk memimpin, maka tujuan yang ingin dicapai tidak akan dapat tercapai secara maksimal.

Teori kepemimpinan membicarakan bagaimana seseorang menjadi pemimpin, atau bagaimana timbulnya seorang pemimpin. Ada beberapa teori tentang kepemimpinan. Menurut Adam Ibrahim Indrawijaya ${ }^{42}$ "pada dasarnya ada dua teori kepemimpinan, yaitu teori sifat (traits theory) dan teori situasiaonal (situational theory)", sementara Wursanto 43 menyatakan ada enam teori kepemimpinan, yaitu; teori kelebihan, teori sifat, teori keturunan, teori kharismatik, teori bakat, dan teori social.

Manajemen akan fleksibel, adaptif, generatif dan produktif dan dapat tetap bertahan pada situasi yang berubah hanya melalui manjemen pembelajaran (learning management). Untuk itu diharapkan organisasi harus mampu menyadap komitmen dan kapasitas anggotanya untuk terus menerus belajar yaitu belajar yang memperbaiki diri untuk mencipta (generative learning).

\footnotetext{
40 Maman Ukas, Manajemen: Konsep, Prinsip, dan Aplikasi, (Bandung : Ossa Promo, 1999). Hlm. 253.

${ }^{41}$ Nanang Fattah, Landasan Manajemen Pendidikan, (Bandung : Rosdakarya, 2000) Hlm. 88.

42 Adam Ibrahim Indrajaya, Perilaku Organisasi, (Bandung: Sinar Baru,1993), Hlm.132-133

43 Wursanto. Dasar-dasar Ilmu Organisasi, (Yogyakarta: Andi, 2002). HIm. 197
} 
Dalam konteks manajemen pendidikan, seorang pemimpin mempunyai peran yang beragam yaitu sebagai designer (perancang); teacher (guru); dan steward (pelayan).

1. Pemimpin sebagai designer (perancang). Esensinya adalah pekerjaan pemimpin dalam perancangan proses belajar, yang dapat digunakan oleh orang-orang dalam organisasi secara keseluruhan untuk secara produktif menyelesaikan isu-isu utama yang mereka hadapi.

2. Pemimpin sebagai teacher (guru). Esensinya pemimpin sebagai guru mempunyai tugas utama mendefenisikan realitas pada empat tingkatan yaitu kejadian/peristiwa, pola dasar perilaku, struktur sistemik dan tujuan cerita.

3. Pemimpin sebagai steward (pelayan). Esensinya adalah pemimpin akan menjadi pengasuh/ penjaga/pengelola visi dalam organisasi. Perasaan untuk mengasuh/menjaga/mengelola yang berhubungan dengan komitmen, dan bertanggungjawab kepada visi tersebut, selain itu juga tugas mereka untuk mengelola kepentingan anggota serta melaihat visi sebagai bagian yang lebih besar.

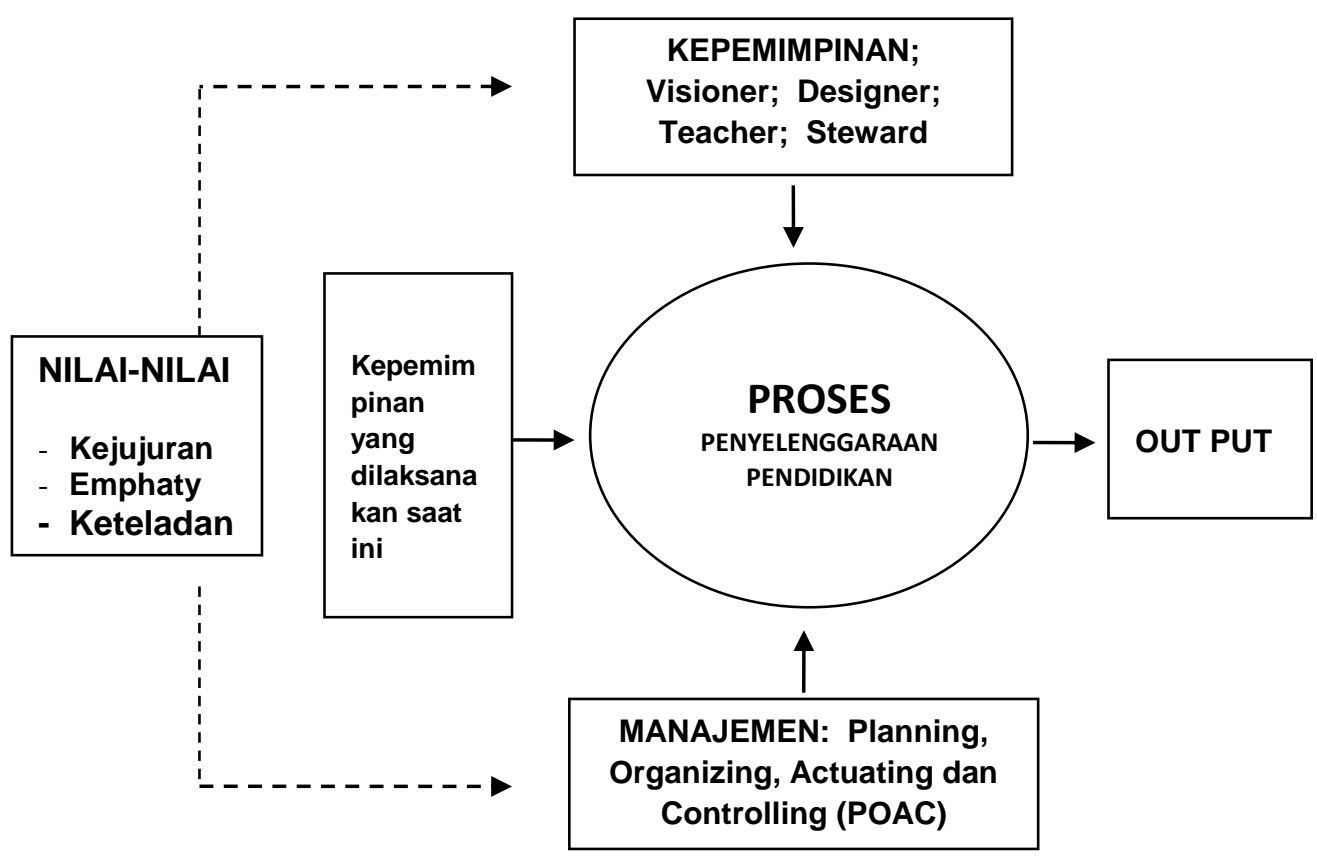

Gambar I: Kerangka Pikir Membangun Kepemimpinan

Dengan demikian, makna kata khalifah yang termaktub dalam Al Qur'an merupakan interpretasi dari peran dan fungsi dari kepemimpinan. Dan 
apabila dikaitkan dengan manajemen pendidikan, maka manajemen yang berbasis pada Al Qur'an melalui gambaran khalifah ini mungkin sesuai dengan konsep yang diakronimkan dengan ZIKR-PIKR dan MIKR, yang dalam arti katanya ZIKR adalah ingat atau sadar, dengan zikr dalam setiap aktivitas akan selalu sadar dan dapat mengontrol diri, MIKR berarti menggunakan akal pikiran untuk selalu membuat inovasi baru dan selalu berkreasi, dan berikutnya PIKR merupakan buah dari Mikr yaitu berupa hasil pemikiran (inovasi) dan kreasi yang berupa program-progam dan pelaksanaannya.

berikut akan sedikit dijelaskan antara ZIKR-PIKR dan MIKR dalam tataran praksis dan operasionalnya.

1. ZIKR merupakan akronim dari Zero base: bersih, jernih setiap saat, Iman: Keyakinan pada janji-janji Allah, Konsisten:: Istiqamah dan Kaffah, Result Oriented: Mengutamakan pencapaian sasaran.

2. PIKR merupakan akronim dari Power Sharing, Information sharing, Knowledge sharing, dan Reward sharing. Pertama, power sharing sama dengan berbagi power yang akan melahirkan aksi (a). Kesiapsiagaan dari pihak yang akan diberi tugas mencakup; kompetensi, penguasaan skill, kerelaan; (b). Prekuensi tugas, semakin rutin sebuah tugas pimpinan merekomendasikan tugas itu secara penuh. (c). Seberapa besar risikonya, Semakin tinggi risiko semakin dituntut kehati-hatian dalam mengambil keputusan. Kedua, information sharing: dalam praktiknya dapat dilakukan misalnya membuka transparansi data sebesar-besarrnya untuk menghindari rekayasa laporan.Ketiga, knowledge sharing, dapat dilakukan misalnya dengan menggali pengalaman dari kru dengan tujuan mengevaluasi, serta reinforcement dalam diri sendiri. Dan Keempat, rewards sharing Selain bonus, team kerja juga akan mendapatkan rewards secara individual yang didasarkan pada unjuk kerja dan prestasi masingmasing, dan juga dapat berupa non materi misalnya pujian ucapan terima kasih dan lain sebagainya.

3. MIKR merupakan akronim dari Militan: berani dan terlatih, Intelek: berakal dan menghargai perbedaan, Kompetitif: efisien dan berdaya saing, serta Regeneratif: patah tumbuh hilang berganti. Pimpinan yang baik adalah pimpinan yang dapat mengkader dan melahirkan generasi penerus yang lebih baik secara berkesinambungan.

\section{E. Penutup}

Al-Qur'an sebagai the way of life dalam memaknai kata "khalifah" sampai saat ini masih dimaknai secara parsial dalam satu topik tertentu. Walau term yang digunakan al-Qur`an untuk menjelaskan tentang 
kepemimpinan diantaranya adalah khalifah, ulu al-amr, imam dan malik, namun keempat term tersebut terkait dengan makna pemimpin sesuai dengan konteks ayatnya. Dari ayat-ayat tentang kepemimpinan, para ulama memberikan penafsiran tentang konsep kepemimpinan bahwa makna kepemimpinan dalam al-Qur`an itu mencakup seluruh pengertian pemimpin meliputi pemimpin risalah, pemimpin kekhalifahan, pemimpin shalat, termasuk juga kepemimpinan dalam dunia pendidikan yang sering dibahas dalam manajemen pendidikannya. Adapun tugas para pemimpin adalah menyeru kebajikan, menegakkan keadilan dan mencegah kedzaliman serta menjalankan "amanat" yang telah dibebankan kepadanya.

Makna khalifah yang termaktub dalam Al Qur'an merupakan gambaran dari peran dan fungsi kepemimpinan khususnya dalam Pendidikan Islam. Dan apabila dikaitkan dengan manajemen pendidikan, maka manajemen yang berbasis pada Al Qur'an melalui gambaran "khalifah" ini akan sesuai dengan konsep yang diakronimkan dengan ZIKR-PIKR dan MIKR, yang dalam arti katanya ZIKR adalah ingat atau sadar, dengan zikr dalam setiap aktivitas akan selalu sadar dan dapat mengontrol diri, MIKR berarti menggunakan akal pikiran untuk selalu membuat inovasi baru dan selalu berkreasi, dan berikutnya PIKR merupakan buah dari Mikr yaitu berupa hasil pemikiran atau inovasi dan kreasi yang berupa program-progam dan pelaksanaannya.

\section{DAFTAR RUJUKAN}

Abdurrahman, M. 2002. Dinamika Masyarakat Islam dalam Wawasan Fikih. Bandung: Remaja Rosdakarya

Al Ba'labaki, Rokhi. 2001. Al Mawrid: A Modern Arabic-English Dictionary. Beirut: Dar Al 'Ilmi Al Malayin.

Al Dazhabi, Muhammad Husain. 2000. Al Tafsir wa Al Mufassiruun Juz I. Mesir: Maktabah Wahbah. Cet. Ke-7. . T.Th . Ilmu At-Tafsir. Kairo: Dar Al-Ma'arif

Al Munawar, Sa'id Aqil Husain.2002. Al-qur'an Membangun Tradisi Kesalehan Hakiki. ( Jakarta: Ciputat Pres

Al Syathi', Aisyah Binti. 1997. Manusia Sensivitas Hermeneutika Al Qur'an. Yogyakarta: LKPSM

Al Thabari, Ibnu Jarir. t.th . Tafsir Al Thabari. Beirut: Dar al Fikr. Juz II. Al Zain, Samikh 'Atif. 2001. Mu'jam Tafsiir Muftadaat Alfadz al Qur'an Al Karim, Fifeteenth Edition. Beirut: Dar Al Kitab Al Lubnaniy. 
Al-Aridl, Ali Hasan. 1992. Sejarah dan Metodologi tafsir, tarj. Ahmad Akrom. Jakarta: Rajawali Press

Al-Azami, M. M. 2005. Sejarah Texs Al-Qur'an dari wahyu sampai Kompilasi. Terj: Sohirin Solihin dkk. Jakarta: GEma Insani Press. Cet. 1

Al-Farmawiy, 'Abdul Hay. 1977. Al-Bidayah fi Tafsir Al-Mawdhu'iy. Kairo, AlHadharah Al-'Arabiyah. Cetakan II.

Al-Khalidi, Mahmud Abdul Majid. 1980. Qawaid Nizham Al-Hukm fi Al-Islam. Kuwait: Darul Buhuts Al-'Ilmiyah.

Anis, Ibrahim et.al. 1972. Al-Mu'jam Al-Wasith. Kair : Darul Ma'arif. Jilid I.

Baidan, Nasruddin. 2002. Metode Penafsiran Al-Qur'an. Kajian Terhadap AyatAyat yang Beredaksi Mirip. Jakarta: pustaka pelajar.

Burhanuddin.1994. Analisis Administrasi Manajemen dan Kepemimpinan Pendidikan, Jakarta,: Bumi Aksara.

Depag RI. 1984. Al-Qur'an dan Terjemahnya. Jakarta: PT. Internusa.

Fattah, Nanang. 2000. Landasan Manajemen Pendidikan. Bandung : Rosdakarya

Gozali, Nanang. 2004. Manusia, Pendidikan dan Sains dalam Pandangan Tafsir Hermenutik. Jakarta: Rineka Cipta.

Hanafi, Hasan. 1989. Al-Yamin wa Al Yasar Fi Al-Fikr Al-Diniy. Mesir: Madbuliy Hidayat, Komaruddin. 1996. Memahami bahasa Agama. Jakarta: Paramadina Indrajaya, Adam Ibrahim. 1993. Perilaku Organisasi. Bandung: Sinar Baru.

Khallaf, Abdul Wahab. 2005. Sejarah Hukum Islam: Ihtisar dan Dokumentasinya, Bandung: Mardja

Ma'luf, Louis dan Bernard Tottel Al Yasu'i. 2000. Al Munjid fi Al Lughah wa al A'lam. Beirut: Dar Al Masyriq. Cet. Ke-38.

Munawwir, Ahmad Warson. 1999. Kamus Al-Munawwir. Yogyakarta: PP. AlMunawwir Krapyak.

Nasir, Ridlwan. 2003. Memahami Al-Qur'an. Surabaya: Indra Media.

Shihab, M. Quraish. 1999. Membumikan Al Qur'an: Fungsi dan Peran Wahyu dalam Kehidupan Masyarakat. Bandung: Mizan. Cetakan. XX. 2001. Wawasan Al Qur'an: Tafsir Maudhu'I atas Pelbagai Persoalan Umat. Jakarta: Mizan. Cetakan XII.

Tim Penyusun Kamus Pusat Bahasa. 2002. Kamus Besar Bahasa Indonesia, Edisi Tiga. Jakarta: Balai Pustaka.

Ukas, Maman. 1999. Manajemen: Konsep, Prinsip, dan Aplikasi. Bandung: Ossa Promo

Wursanto. 2002. Dasar-Dasar Ilmu Organisasi. Yogyakarta: Andi. 